\title{
APLIKASI DAN PRINSIP BELAJAR DALAM PEMBELAJARAN BAHASA ARAB PERGURUAN TINGGI MINORITAS MUSLIM
}

\author{
Ismail Suardi Wekke*, Faishol** \\ * Sekolah Tinggi Agama Islam Negeri (STAIN) Sorong \\ **Universitas Islam Negeri (UIN) Maulana Malik Ibrahim Malang \\ Email: iswekke@gmail.com
}

\begin{abstract}
ABSTRAK
Belajar bahasa Arab dalam setiap tingkatan pendidikan formal berbeda antara satu jenjang dengan kelas lainnya. Dengan demikian, kelas-kelas pembelajaran bahasa Arab di perguruan tinggi memiliki kekhasan tersendiri. Untuk itu, penelitian ini akan menganalisis situasi pembelajaran di perguruan tinggi minoritas muslim. Studi kasus penelitian mengkaji secara khusus Sekolah Tinggi Agama Islam Negeri (STAIN) Sorong. Penelitian ini menunjukkan dua hal yaitu aplikasi dan prinsip belajar yang dipraktikkkan dalam mengakselerasi keterampilan berbahasa mahasiswa. Beberapa kegiatan tambahan yang dilaksanakan diluar jam pelajaran untuk membantu penguasaan berbahasa. Termasuk dengan program intensifikasi selama satu semester dengan pembelajaran yang mengutamakan pada kemampuan penguasaan studi Islam. Usaha ini dilakukan untuk mengintegrasikan keterampilan berbahasa yang akan dijadikan sebagai pemahaman awal dalam kajian beberapa materi keislaman yang mempersyaratkan kemampuan berbahasa Arab. Keterampilan paling minimal yang diperlukan adalah kemampuan membaca dengan pemahaman pada ide tulisan. Akhirnya, aplikasi dan prinsip diterapkan menjadi model tersendiri untuk menuntaskan capaian belajar yang dituju.
\end{abstract}

Kata kunci: capaian belajar, aplikasi, prinsip

\section{PENDAHULUAN}

Bahasa menjadi alat untuk menyatakan identitas diri dan pengertian terhadap lingkungan yang didiami (Mubarok, 2007). Dimulai dari pemahaman tentang hukum-hukum belajar, ini dapat digunakan untuk aplikasi pembelajaran bahasa. Belajar bahasa jikalau diiringi dengan pemahaman teoritis, kemudian dilaksanakan dengan mengacu kepada prinsip belajar bahasa, disertai pula dengan aktivitas yang menumbuhkan ciri pembelajar bahasa yang produktif, akan menjadi sebuah sinergi dalam mengajarkan materi bahasa asing. Mengajarkan bahasa menjadi sebuah tantangan tersendiri dimana diperlukan keinginan siswa dan juga kreativitas guru. Jikalau dua unsur ini dilaksanakan dengan bersinergi antar yang satu dengan lainnya, akan membentuk pengalaman belajar yang akan mencapai hasil belajar yang baik. Sinergi antara guru dan murid menjadi sebuah kolaborasi dalam pencapaian tujuan belajar (Dojer, 2016). 
Dosen membantu mahasiswa dalam pembentukan lingkungan belajar yang kondusif (Ke, Lee, $\& \mathrm{Xu}, 2016)$.

Kreativitas dalam berbahasa diperlukan untuk menumbuhkan kegairahan dalam belajar. Daya kreativitas dalam istilah teori generatif-transformasi memberikan penekanan pada pentingnya peran kreatif sebagai sifat dasar kolektif manusia. Kreativitas yang dimaksudkan dalam hal ini adalah kemampuan manusia untuk menuturkan bahasa tertentu sekaligus memahami unsur-unsur dalam bahasa itu secara tidak terbatas. Kemudian, mengolahnya, menentukan salah dan benar, menggunakan kaidah-kaidah yang terbatas. Dalam pandangan teori ini, studi bahasa sejatinya adalah pendeskripsian media (Besançon \& Lubart, 2008). Dengan media bahasa dapat membentuk atau menciptakan kata baru yang kemudian menjadi kesepakatan. Dengan kata yang baru tentu akan ada ide baru. Walaupun sebelumnya tidak pernah wujud dan menjadi bahan pemikiran individu lain (Zakariya, th).

Pandangan teoritis dalam kaitannya dengan bahasa dan kecakapan berbahasa memperkenakan teori belajar bahasa. Secara garis besar pandangan itu terbagi dalam tiga arus utama yaitu pandangan struktural, pandangan fungsional, dan pandangan interaksional. Pandangan struktural merupakan pandangan yang paling awal sekali hadir. Secara tradisional, teori ini melihat bahwa bahasa merupakan struktur yang saling berhubungan. Dengan unsurunsur yang melekat di dalamnya, maka untuk menguasai bahasa haruslah menguasai kesatuankesatuan bahasa yang terdiri atas fonologis, gramatikal, dan leksikal. Adapun pandangan fungsional menjadi gerak bagi ekspresi makna yang dilaksanakan sesuai dengan fungsinya masing-masing. Bahasa tidaklah sebatas pada aspek tata bahasa tetapi melampaui semua itu dengan bentuk semantik dan komunikatif. Silabus yang dibangun atas pandangan ini akan menjabarkan pandangan fungsional dalam bentuk implikasi sebagai sebuah kebutuhan yang wujud dalam masyarakat penutur bahasa itu. Masalah yang sama juga ditemukan dalam kasus perguruan tinggi di Arab sekalipun (Al-krenawi, 2016). Sementara pendidikan Islam di kawasan minoritas muslim juga berfungsi sebagai penggerak pengembangan masyarakat (Wekke, 2013).

Selanjutnya, pandangan interaksional. Bahasa dalam pandangan ini menitikberatkan pada perspektif bahwa hubungan antara pribadi dan perfomansi untuk kepentingan transaksi sosial hanya dapat menggunakan bahasa sebagai medianya. Dengan bahasalah akan wujud kreasi dan pemeliharaan hubungan sosial. Dalam ketiganya akan terbentuk aksioma dan 
kerangka kerja secara teoritis yang dijadikan sebagai pijakan untuk aplikasi pembelajaran bahasa. Hanya saja, tetap saja diperlukan tambahan dari teori pembelajaran bahasa lainnya untuk melengkapi ketidaksempurnaan pandangan yang sudah ada sehingga dengan adanya pelbagai pandangan yang berbeda akan memberikan kelengkapan dan kesempurnaan dalam proses belajar. Beberapa kajian pembelajaran bahasa Arab sebatas pada pembelajaran aktif (Yusuf \& Wekke, 2015), pendekatan multikultural (Lubis \& Wekke, 2009), dan model pembelajaran bahasa Arab (Wekke, 2014).

Dalam teori bahasa paling tidak perlu jawaban atas dua pertanyaan. Pertama, perlu sebuah jawaban tentang bagaimana proses kognitif yang terlibat untuk menguasai bahasa. Kedua, pertanyaan yang berkaitan dengan kondisi apa yang harus diciptakan sehingga proses belajar bahasa dapat terselenggara dengan baik untuk mendukung penguasaan keterampilan.

\section{BEBERAPA HUKUM BELAJAR}

Lindsay dan Norman mengemukakan teori hukum-hukum belajar dalam tiga kesimpulan. Pertama, hukum hubungan kausal. Sebuah organisme perlu menguasai hubungan antara aksi yang spesifik dengan hasil yang menjadi keluaran. Sehingga dengan menguasai ini, akan mengerti bagaimana dapat menguasai keterampilan sebagai hasil dari belajar hal-hal yang spesifik. Kedua, hubungan hubungan belajar. Terdiri atas dua bagian. Jikalau menginginkan penguasaan terhadap keluaran tertentu, maka diperlukan pengulangan sehingga dapat menjadi penghubung bagi keterampilan tertentu. Selanjutnya, untuk hasil yang tidak diinginkan, maka hanya perlu dihindari sehingga tidak terdapat relasi memungkinkan untuk menyimpan memori tentang tindakan tersebut. Terakhir, hukum umpan balik informasi. Adanya sebuah informasi akan menjadi informasi berikutnya (Lindsay, 1977).

Bagi Norman belajar dan mengingat merupakan dua hal yang berdekatan. Tetapi belajar merupakan hal yang lebih sederhana dibandingkan dengan mengingat. Norman memilih menggunakan kata belajar untuk menunjukkan tindakan yang spesifik berhubungan dengan materi. Dengan materi itulah yan dapat diulang-ulangi sekaligus digunakan sebagai sebuah keterampilan. Belajar melibatkan aktivitas mengingat yang terencana dan disertai dengan keterampilan (Norman, 1982). Pada bagian inilah kemudian menjadi penanda untuk belajar dan mengingat. Apa yang sudah dilakukan dapat menjadi menjadi penyebab untuk dipelajari atau diingat. Sementara jikalau tidak ada kegiatan sama sekali yang berhubungan dengan hal 
tersebut, maka tidak akan membangkitkan memori sama sekali. Dengan adanya sebuah informasi, ini akan menambah sistem struktur memory. Masalah yang dihadapi seseorang yang belajar adalah berusaha mendapatkan kondisi yang relevan dengan situasi yang diinginkan. Ini sebagai langkah dalam menempatkan pengalaman yang sesuai dan juga merekam informasi secara tepat.

Lingkungan yang memaksa merupakan sebuah instrumen yang dapat digunakan dalam pembelajaran bahasa. Ketika sekelompok siswa berada dalam lingkungan yang kesemua mitra wicara bertutur dalam bahasa Arab maka tentu siswa-siswa akan berusaha mengerti apa yang dituturkan orang-orang sekelilingnya. Sementara jikalau tetap saja menggunakan pola terjemahan, maka cenderung akan mengharapkan pemaknaan dari apa yang dituturkan pribadi yang tidak dimengertinya. Seperti jika berkunjung ke negeri Tiongkok dimana bahasa ibu adalah bahasa Mandarin. Tentu wisatawan akan berusaha mengerti beberapa kalimat yang digunakan dalam interaksi. Walaupun wisatawan hanya berkunjung dalam waktu yang singkat tetapi mereka tetap saja berusaha menguasai bahasa Mandarin. Sebaliknya ketika wisatawan berkunjung ke India. Mereka tidak kesulitan mendapatkan orang-orang yang bertutur bahasa Inggris. Sehingga tidak perlu mempelajari bahasa Hindi. Untuk dua contoh negara di atas ini merupakan gambaran bagaimana lingkungan yang memaksa seseorang untuk senantiasa menggunakan bahasa yang dituturkan dalam lingkungannya. Kendala bahasa menjadi sebuah kondisi untuk memaksakan perhatian sehingga dapat berinteraksi dengan lingkungan. Tanpa penguasaan akan bahasa yang digunakan oleh penutur lingkungannya mereka tidak akan mendapatkan makna dan pesan yang dikirimkan oleh mitra wicara.

Bahasa bukanlah hanya sekadar pada keterampilan berbahasa. Tetapi lebih dari itu diperlukan juga kompetensi komunikasi untuk sehingga kemampuan linguistik ketika berada dalam bentuk teks dan juga dituturkan menempati posisi yang kontekstual. Kompetensi komunikasi mengiringi kemampuan kebahasaan karena bahasa adalah alat sosial yang digunakan dengan orang lain. Tidak hanya dalam bentuk teks semata-mata. Kompetensi bahasa berkaitan dengan tata bahasa dan pembentukan kata menjadi kalimat. Sementara kompetensi komunikasi merupakan metode dan kaidah untuk menyampaikan bahasa tersebut kepada pihak lain sehingga dapat dipahami sesuai dengan maksud yang diinginkan penuturnya. Sehingga dengan kesatuan keterampilan ini dapat menempatkan pada pemahaman 
dan penggunaan secara bersamaan. Apa yang disampaikan juga dipahami dan berada dalam kata dengan kalimat tepat dan proporsional.

Dalam perkembangannya kompetensi kemudian terbagi menjadi empat bagian: pertama, kompetensi tatabahasa (grammatical competence). Kemampuan yang berhubungan dengan fonetik, morfologi, semantik, dan sintaksis. Begitu juga dengan kemampuan mengetahui kosa kata. Kompetensi bahasa (kifaayah al-lughawiyah) dapat saja dikuasai tanpa perlu duduk secara formal dalam kelas bahasa asing. Kedua, kompetensi komunikasi (discourse competence). Dalam bertutur, kemampuan membentuk percakapan yang mempunyai makna, baik lisan maupun tulisan secara gradual, berangsur-angsur, bersambung, dan saling terkait. Ketiga, kompetensi bahasa berhubungand engan sosial kemasyarakatan (sociolinguistic competence). Kemampuan mengetahui kaidah dan budaya masyarakat dalam mengkomunikasikan bahasa yang dituturkannya. Keterampilan ini harus dikuasai penutur agar dapat memahami bagaimana karakteristik konteks sosial kemasyarakatan dalam berkomunikasi. Sebab walaupun dalam kalimat yang sama, tetapi dapat digunakan dalam bentuk yang berbeda-beda sesuai dengan siapa dan waktu ketika bahasa itu digunakan. Terakhir, kemampuan strategi (strategic comptence). Kompetensi ini berkaitan dengan kemampuan membuat dan menerapkan metode dan media, baik verbal maupun nonverbal untuk membantu penutur ketika mendapatkan kesulitan dalam menyampaikan maksud tertentu kepada penerima pesan. Saat penerima pesan kesulitan untuk mendapatkan kandungan maka diperlukan usaha untuk mengulanginya, menjelaskan bentuknya dalam susunan yang berbeda, gerak-gerik tangan dan wajah dikalau diperlukan penjelasan lebih lanjut (Brawn, th).

Dengan berpijak pada kompetensi komunikasi yang menjadi bagian dari kompetensi ketika belajar bahasa, maka lahirlah pandangan berikutnya yang memberikan tempat bagi siswa untuk diajak berpikir, selanjutnya menggunakan aktivitas berpikir itu dalam bagian untuk belajar bahasa. Hukum ini juga menghimabu kepada guru untuk mengajarkan bahasa yang dimulai dari bentuk-bentuk yang fungsional. Untuk memberikan aplikasi dalam bentuk metode, maka disebutlah pendekatan komunikatif sebagai cikal bakal untuk memberikan penjelasan bagaimana kompetenesi komunikasi digunakan dalam kaitan mengajarkan bahasa dengan menggunakan pola-pola komunikasi secara nyata.

Belajar bahasa Arab tidak dapat melepaskan diri dari pandangan ideologi. Walaupun juga pandangan ideology Arab dewasa ini sangat beragam (Taha-Thomure, 2008). Ini karena 
bahasa Arab merupakan bahasa satu-satunya yang digunakan al-Quran. Secara fungsional, bahasa Arab juga merupakan bahasa antar manusia. Hanya saja, dalam urusan ritual keagamaan, bahasa Arab juga menjadi bahasa yang digunakan untuk berkomunikasi dengan Allah. Bahasa dunia, selain dari Bahasa Arab, selalu saja memiliki ruang tafsir yang terbuka dengan asumsi pada realitas politik. Pertama, bahasa ditandai dengan ketidakstabilan dan ketidaktepatan makna. Kefanaan ini terjadi karena dengan sendirinya bahasa menjadi medan yang terbuka untuk dimaknai sekaligus kotak terbuka yang memungkinkan atribut yang berada di luar bahasa untuk masuk ke dalamnya. Untuk itu, fenomena, kepentingan, atau kehendak menjadi sangat subyektif untuk mengiringi bahasa terhadap makna. Kedua, ketidakstabilan dan ketidaktepatan itu menyebabkan tidak ada metode analisis yang memiliki status istimewa. Baik secara tekstual maupun memiliki wilayah otoritas tersendiri. Ketiga, pada posisi dengan ketidakstabilan dan ketidakmapanan tafsir menjadikan kegiatan selalu tidak tak terbatas. Sementara itu, bahasa Arab fusha yang kemudian dikenal juga dengan Modern Standar Arabic (MSA) namun tetap saja setiap negara di Teluk memiliki dialek tersendiri (Abuata \& Al-omari, 2015).

Uraian tidak berlaku terhadap bahasa Arab. Dimana tafsir al-Quran memiliki otoritas dan juga hanya dapat dilakukan oleh orang yang menguasai bahasa Arab sebagai alat utama untuk menjelaskan makna yang dikandung sebuah ayat (Nørreklit \& W. Scapens, 2014). Tetapi ini tidak dapat memasukkan unsur subyektifnya begitu saja. Selalu ada keterkaitan dengan penjelasan yang datangnya berupa wahyu dan ini adalah berupa hidayah yang datangnya hanya dari Allah semata. Untuk itu, pandangan seperti ini akan selalu menjadi bagian dari ketika belajar bahasa Arab. Bahasa Arab juga tidak pernah dimaksudkan sebagai alat untuk mengatur kehidupan manusia yang datangnya dari manusia (Sobur, 2006). Melainkan merupakan bagian dari ide, gagasan, dan kehendak yang datangnya dari Allah.

\section{TEORI BELAJAR BAHASA}

Belajar bahasa merupakan proses peniruan. Keterampilan yang dicapai adalah sejauhmana bagaimana bahasa yang dipelajari dapat ditiru dan dikuasai termasuk dalam pemaknaan. Anak-anak dan orang dewasa dalam kapasitasnya masing-masing memiliki kemampuan untuk menguasai asal dalam belajar bahasa. Anak-anak lebih awal menguasai makna. Sementara orang dewasa lebih menguasai permukaan yang diawali dalam mekanisme 
hafalan. Untuk itu, ketika pembelajaran bahasa berlangsung diperlukan juga konteks yang bermakna. Tidak semata-mata hanya sibuk untuk melihat fungsi dan tujuan bahasa.

Meniru mengacu kepada praktik yang sudah berlangsung di masyarakat. Penutur bahasa India senantiasa akan menggerakkan kepalanya ketika berbicara karena itulah yang dilihatnya di masyarakat. Dengan berusaja meniru apa yang sudah dilaksanakan anggota masyarakat lainnya, ini merupakan usaha untuk menjadi bagian masyarakat itu. Sejak semula ketika berusaha untuk meniru ucapan yang didengarnya dari orang lain, maka terlihat pula bagaimana ekspresi yang digunakan di saat mengucapkan bahasa itu. Begitulah secara turun temurun dipahami walaupun tidak dijelaskan secara formal bagaimana kata itu ketika diucapkan. Pemahaman akan apa yang boleh dilakukan dan larangan di masyarakat juga menjadi proses belajar yang berlangsung pada saat yang sama. Termasuk pula keberadaan konsonan dan vonem yang ada dalam bahasa ibu itu akan diserapnya melalui interaksi ketika berkomunikasi.

Ketika proses meniru berlangsung, diperlukan frekuensi latihan yang memadai. Untuk sebuah bahasa tidak hanya diperlukan kemampuan memahami struktur tetapi lebih kepada penggunaan bahasa yang dipelajari secara terampil menggunakannya. Ketika hafalan dilakukan, maka fokus pelajaran semata-mata hanya pada kemampuan kognitif. Ini bahkan akan menimbulkan kekhawatiran siswa untuk menggunakan bahasa yang dipelajarinya. Kemampuan yang dimilikinya selalu mendorong untuk takut dalam menggunakan bahasa. Ini karena pola yang diorientasikannya selalu kepada kesempurnaan gramatikal. Sehingga penguasaan bahasa harus dilalui dengan assesmen bagaimana tujuan yang akan dicapai. Fokus tahapan pembelajaran yang akan dilalui disesuaikan dengan keterampilan yang akan dikuasai pada akhir program yang dijalankan.

Pembelajaran bahasa menjadi sebuah langkah yang harus terencana. Tidak dapat dilakukan secara serampangan dan tanpa arah yang jelas. Program langkah demi langkah sudah harus ditetapkan sehingga capaian yang akan dituju sudah jelas sejak awal. Dengan kejelasan seperti ini, proses belajar dapat terarah dan dapat dilaksanakan dengan mudah. Bahkan sebuah program kecil dapat saja berdampak besar. Pembelajaran bahasa di masjid madrasah setiap Shubuh dan Ashar memberikan kesempatan bagi siswa untuk melatih kemampuan berbahasa. Walaupun hanya dilaksanakan masing-masing kurang dari sejam tetap saja menjadi latihan bagi siswa dalam menempuh pembelajaran bahasa yang produktif. 
Akumulasi dari waktu belajar yang berlangsung sepanjang tahun pelajaran merupakan sebuah stimulasi agar mampu menguasai bahasa dengan membentuk kebiasaan.

Sebagai bagian fundamental dari keseluruhan perilaku manusia, bahasa menempati posisi yang khas. Teori behavioristik menggambarkan bahwa perilaku linguistik merupakan hubungan atau kaitan dengan lingkungan sekitar. Bahasa adalah tanggapan terhadap stimulus. Jika ini diransang secara berulang, maka akan menjadi kondisi kebiasaan. Ini penjelasan tentang anak-anak yang menyalin apa yang dilakukan oleh orang dewasa. Mereka berusaha menyamai apa yang ada dalam lingkungan. Dalam pandangan seorang anak wujud kepantasan semata-mata tergantung kepada apa yang dilakukan oleh orang dewasa.

Karya klasik Skinner yang menjelaskan percobaan dengan perilaku binatang (Skinner, 1957). Jikalau sebuah perilaku mendatangkan imbalan, maka akan dipertahankan. Sebaliknya jikalau itu mendatangkan hukuman, maka akan dihentikan. Frekuensi dan tingkatannya akan berubah seiring dengan penghargaan dan hukuman yang didapatkan. Penjelasan tambahan dari Skinner (1968) berkenaan dengan mesin pengajaran dan pembelajaran yang terprogram. Kedua penjelasan ini tetap mengacu kepada teori behavioristik bahwa apapun yang dikehendaki dapat dimulai salah satunya dari stimulus yang dikondisikan dalam lingungan.

Dengan aplikasi teori behavioristik dalam pembelajaran bahasa berusaha untuk memodifikasi tingkah laku dan adat kebiasaan untuk menunjang proses belajar. Skinner menjelaskan dalam bentuk bahwa untk belajar bahasa diperlukan tingkah laku verbal (Skinner, 1961). Sekaligus juga memerlukan adanya keadaan lingkungan yang mampu memberikan dorongan untuk terus belajar secara aktif. Pandangan behavioristiklah yang kemudian memengaruhi proses belajar bahasa yang selalu memerlukan lingkungan dan perlakukan secara khusus. Ini dilakukan semata-mata untuk memberikan dorongan dari sekeliling sehingga belajar bahasa lebih mudah untuk dilakukan. Dengan kondisi lingkungan pula akan tercipta atmosfir belajar. Kalau itu sudah tersedia, maka siswa dengan sendirinya akan terdorong untuk menyesuaikan diri dengan keadaan lingkungan. Jikalau tidak dapat melakukan adaptasi, maka dia akan menarik diri dari lingkungan yang ada.

Secara umum ada tiga pandangan teoritis yang mengkonstruksi metode pembelajaran bahasa. Pertama, pandangan tradisional dan ini yang paling awal sekali muncul yaitu pandangan struktural (structural view). Bahasa dilihat sebagai sebuah sistem yang terstruktur dan saling berkaitan untuk memberikan makna pada sebuah kode. Target pembelajaran jika 
menggunakan teori ini adalah fokus pembahasan pada fonologi, tata bahasa, dan unsur leksikal. Kedua, pandangan fungsional. Bahasa dilihat sebagai alat untuk mengekspresikan makna yang tertentu untuk kepentingan sesuai dengan kondisinya masing-masing. Teori ini menitikberatkan pada persoalans emantik dan dimensi komunikasi dibandingkan pada karakter gramatikal. Ketiga, pandangan interaksional (interactional view). Pandangan ini menjelaskan bahwa bahasa merupakan realisasi fungsional dan hubungan interpersonal. Sebagai sebuah transaksi antar individu bahasa menjadi alat untuk mengkreasi dan memertahankan hubungan sosial (Richard dan Rodgers, 1995).

Ketiga teori ini menurunkan masing-masing metode yang menjadi lanjutan pandangan teoritis. Sehingga jikalau memandang sebuah bahasa dalam bentuk sesuai dengan apa yang disampaikan masing-masing pakar pendukung teori tersebut tentu akan menghasilkan metode yang berbeda. Pada akhirnya, kemampuan yang diasah juga memiliki kekhasan masingmasing. Setiap teori memberikan perhatian pada unsur bahasa yang berbeda. Namun demikian, dapat saja digabungkan dan dikembangkan untuk mendapatkan kemampuan berbahasa yang paripurna. Jikalau ketiga teori tersebut ingin diiplementasikan, maka perlu menggunakan metode yang menjadi alat dalam penerapan untuk mencapai hasil yang diharapkan.

\section{PRINSIP BELAJAR BAHASA}

Belajar bahasa merupakan kebiasaan. Pandangan psikologi behavioristik menjelaskan perilaku ini. Gambaran awalnya adalah eksperimen klasik yang ditunjukkan Pavlov dan kotakkotak Skinner. Ini mendeskripsikan bahwa makhluk hidup sekalipun yang tidak memiliki akal pikiran bisa dikondisikan sebagaimana keinginan pelatih. Binatang itu akan bereaksi dengan diberikan imbalan dan hukuman dalam tingkat dan penjadwalan yang ketat. Jikalau ini diterapkan dalam pembelajaran dengan subyeknya manusia, maka akan lebih mudah karena disertas dengan prakarsa dan kemampuan yang komprehensif. Sementara beberapa faktor yang dimiliki manusia tidak berada dalam kemampuan eksperimen yang sudah dijalankan Pavlov dan Skinner.

Empat langkah yang digunakan dalam untuk memahami bagaimana setiap organisme mempelajari sesuatu. Pertama, entry behavior (perilaku awal). Dengan mengetahui apa yang sudah dikuasai siswa, maka akan dikembangkan tahapan lanjutan. Keterbatasan yang ada 
hendak disingkirkan, sementara kemampuan yang sudah dikuasai akan dikuatkan. Termasuk memberikan rangsangan sesuai dengan kebutuhan yang diperlukan.

Kedua, tujuan akhir yang akan dicapai mesti dirumuskan secara eksplisit. Dengan memberikan pengarahan bagaimana merumuskan tujuan itu, siswa akan mengetahui pencapaian yang diinginkan pada bagian akhir proses yang dijalani. Ini juga akan menjelaskan bagaimana tampilan yang akan wujud jikalau menjalani program-program yang akan diikuti.

Ketiga, rancangan beberapa metode pelatihan. Metode yang digunakan tidak monoton. Mesti ada beberapa variasi dan ragam aktivitas yang digunakan sehingga akan membantu proses belajar dilakukan. Terakhir, sebuah prosedur evaluasi yang dilakukan secara komprehensif. Dengan pola penilaian sesuai dengan apa yang dilaksanakan akan tergambar keberhasilan sekaligus kelemahan dari pelaksanaan program. Evaluasi tidak saja akan memberikan angka dan rangking tetapi dengan evaluasi akan memberikan data dan informasi bagaimana perkembangan para peserta didik dalam penguasaan materi belajar. Evaluasi juga bertujuan untuk merancang langkah-langkah pembelajaran yang akan dilakukan selanjutnya. Jikalau saja dalam pembelajaran sebelumnya lebih banyak kekurangan, maka program remedial dapat dilaksanakan untuk memberikan pengulangan bagi materi belajar yang belum dikuasai. Sementara itu, dengan evaluasi juga dapat diketahui bagian mana dalam materi belajar yang sudah dimengerti dan bagaimana pengertian itu dalam bentuk keterampilan.

Dalam belajar bahasa melibatkan kekeliruan dan kesalahan. Dalam konteks belajar, maka selalu saja kekeliruan akan terjadi. Ini setara dengan salah penilaian, salah perhitungan, dan asumsi-asumsi yang tidak tepat. Setelah mendapatkan informasi yang sesuai dengan konteks tetapi tetap saja terjadi kekeliruan, maka ini sudah bergeser menjadi kesalahan. Bisa saja pelajaran dimulai dari kekeliruan. Pada tahap selanjutnya, belajar dari kekeliruan itu dan sekaligus menghindarinya adalah proses untuk menuju perbaikan. Adanya umpan balik, koreksi, dan informasi yang tepat merupakan usaha-usaha untuk mendekati tujuan yang dikehendaki. Bahasa akan selalu dipandang benar atau salah dari sudur gramatikal. Seorang anak akan diberikan koreksi berdasarkan pandangan tata bahasa yang dianut orang dewasa. Ketika sudah mendapatkan umpan balik, maka sang anak akan memberikan respon dalam bentuk koreksi demi koreksi sampai bahasa yang digunakannya dapat diterima mitra wicara yang lain. Justru ketika tidak berbuat kekeliruan, maka tahapan yang dilaluinya tidak akan 
komprehensif. Bagian dari kekeliruan ataupun kesalahan menjadi bagian yang dipelajarinya sehingga dapat membangun sistem kesadaran akan aturan kebahasaan yang dipelajarinya.

Belajar bahasa tidak dapat menghindari kesalahan. Prinsip mengambil resiko (risk taking) bermanfaat bagi menumbuhkan keberanian siswa untuk tidak pernah takut menggunakan bahasa yang dipelajari. Siswa harus terbiasa dalam mengambil resiko dengan tidak takut untuk bermasalah. Dengan atmosfir yang kreatif dan suasana yang kondusif akan menjadi sebuah dorongan dalam menggunakan bahasa target. Sekaligus dalam pelaksanaan praktik, guru memberikan pujian bagi keberhasilan yang sudah dicapai. Mahasiswa dapat saja melakukan kesalahan, ketika mereka melakukan kesalahan itu, maka dosen sebagai sumber belajar bersama-sama dengan mahasiswa untuk memedomani kaidah yang baku. Hanya saja, ketika kesilapan dilakukan bukanlah sebuah kesalahan (Bernales 2016).

Pada tahap awal belajar bahasa diperlukan sebuah asosiasi bahasa yang dipelajari dengan bahasa ibu yang dituturkan. Tetapi ini tidak berarti harus membandingkan. Bahkan harus menghindari proses belajar bahasa yang membanding-bandingkan antara bahasa target dengan bahasa ibu. Masing-masing bahasa memiliki kekhasan masing-masing. Kecuali kalau itu sudah pada tahap lanjut dan untuk keperluan kajian kebahasaan secara khusus di departemen linguistik. Tetapi jikalau hanya untuk kepentingan belajar bahasa sebagai sebuah keterampilan, hanya diperlukan asosiasi dan bukannya komparasi. Ini untuk menghindari pembelajaran lebih banyak membahas materi teoritis tetapi kurang pada penguasaan untuk keterampilan berbahasa. Madrasah semata-mata memberikan alokasi waktu dan materi untuk penguasaan materi bahasa Arab. Selain di jurusan keagamaan dan bahasa, keduanya memang sudah mulai menambah materi belajar untuk mengarah ke tingkat lanjut. Selain itu, bahasa Arab sebagai mata pelajaran untuk keterampilan semata.

Ciri utama belajar bahasa di perguruan tinggi, tidak lagi dimulai dari pembelajaran awal. Mahasiswa sudah menempuh jenjang pendidikan sebelumnya. Sehingga pembelajaran digunakan dengan androgogi. Tidak lagi menggunakan prinsip-prinsip belajar di madrasah (Wekke, 2016). Mereka menggunakan kesempatan belajar di perguruan tinggi untuk kepentingan kapasitas profesional (Burrow, Mairs, Pusey, Bradshaw, \& Keady, 2016). Dengan harapan bahwa perguruan tinggi akan menjadi fasilitator bagi transformasi masyarakat (Arab, Europe, America, \& War, 2016). Sebuah kesempatan untuk mempergunakan multimedia sebagai sarana pembelajaran (Yousafzai, Chang, Gani, \& Noor, 2016). Terakhir, karena ini 
materi kebahasaan, maka prinsip lama masih berlaku sampai saat ini, berlatih akan memberikan kesempatan menuju kesempurnaan (Ye, Liu, Liu, Tang, \& Zhao, 2016).

\section{PENUTUP}

Selalu saja ada pembaruan yang muncul dari waktu ke waktu sebagai respon dari masalah yang muncul dalam persoalan pendidikan bahasa. Maka, dengan adanya teori ataupun pandangan baru merupakan sebuah kreativitas untuk melengkapi apa yang sudah ada sebelumnya. Sekaligus mengisi apa yang tidak dapat dipenuhi oleh metode yang sudah wujud. Kemampuan inilah juga yang membentuk inovasi. Dengan bergulirny ainovasi akan memberikan daya dorong bagi kemajuan pengetahuan dan aplikasinya dalam bentuk teknologi. Akibatnya, penemuan dari waktu ke waktu terus berkembang dan mendapatkan penambahbaikan dari penemu terkini. Mengatasi kelemahan yang sudah ada, memberikan cara yang lebih sederhana, dan terobosan yang lebih ringkas untuk menghemat tenaga dan mengefektifkan penggunaan waktu untuk melakukan banyak hal lain.

Kemauan untuk belajar bahasa tidak terlepas dari kondisi yang menjadi latar belakang setiap pelajar. Untuk itu, dengan memahami kondisi setiap pribadi akan menjadi daya dukung dalam mengajarkan sebuah bahasa. Juga, bahasa menjadi alat untuk menyatakan simbol dan selanjutnya itu menjadi tradisi dan menjelma menjadi adat. Untuk itu, ketika belajar bahasa dengan mulai memberikan penjelasan berkenaan dengan simbol-simbol itu akan menajdi sebuah koneksi belajar yang berhubungan dengan lingkungan yang ada.

\section{DAFTAR PUSTAKA}

Abuata, B., \& Al-omari, A. (2015). A rule-based stemmer for Arabic Gulf dialect. Journal of King Saud University - Computer and Information Sciences, 27(2), 104-112.

Al-krenawi, A. (2016). Higher education among minorities: The Arab case. International Journal of Educational Research, 76, 141-146.

Arab, T., Europe, W., America, N., \& War, S. W. (2016). Higher education in a transforming society: The case of Arabs in Israel. International Journal of Educational Research, 76, 89-95.

Bernales, C. (2016). Towards a comprehensive concept of Willingness to Communicate : Learners' predicted and self-reported participation in the foreign language classroom. System, 56, 1-12.

Besançon, M., \& Lubart, T. (2008). Differences in the development of creative competencies in children schooled in diverse learning environments. Learning and Individual Differences, 18(4), 381-389. 
Brawn, D. (tth). Usus Ta'allum al-Lughah wa Ta'liimiha. Ttpt: tp.

Burrow, S., Mairs, H., Pusey, H., Bradshaw, T., \& Keady, J. (2016). Continuing professional education: Motivations and experiences of health and social care professional' $s$ parttime study in higher education. A qualitative literature review. International Journal of Nursing Studies, 63, 139-145.

Dojer, N. (2016). Learning Bayesian networks from datasets joining continuous and discrete variables. International Journal of Approximate Reasoning, 78, 116-124.

$\mathrm{Ke}, \mathrm{F}$., Lee, S., \& Xu, X. (2016). Teaching training in a mixed-reality integrated learning environment. Computers in Human Behavior, 62, 212-220.

Lindsay, P. H. dan Norman, D. A. Human Information Processing: An Introduction to Psychology (edisi kedua. New York: Academic Press.

Mubarok, A. Z. Pendekatan Struktualisme Linguistik dalam Tafsir al-Quran Kontemporer "ala” M. Syahrur. Yogyakarta: elSAQ Press.

Norman, D. A. Learning and Memory. New York: Freeman.

Nørreklit, H., \& W. Scapens, R. (2014). From persuasive to authoritative speech genres. Accounting, Auditing \& Accountability Journal, 27.

Richard, J. C dan dan Rodgres, T. S. (1986). Approaches and Methods in Languange Teaching: A Description and Analysis. Cambridge: Cambdridge University Press.

Richards, J. C. dan Rodgers, T. S. (1995). Approaches and Methods in Languange Teaching. New York: Cambridge University Press.

Skinner, B. F. (1957). Verbal Behavior. New York: Macmillan.

Skinner, B. F. (1961). Behavior Modification. NewYork: Appleton Century Crofts.

Skinner, B. F. (1968). The Technology of Teaching. New York: Appleton-Century-Crofts.

Sobur, A. (2006). Analisis Teks Media: Suatu Pengantar untuk Analisis Wacana, Analisis Semiotik, dan Analisis Framing. Bandung: PT. Remaja Rosdakarya.

Taha-Thomure, H. (2008). The status of Arabic language teaching today. Education, Business and Society: Contemporary Middle Eastern Issues, 1(3), 186-192.

Wekke, I. S. (2013). Religious education and empowerment: study on pesantren in muslim minority West Papua. MIQOT: Jurnal Ilmu-ilmu Keislaman, 37(2).

Wekke, I. S. (2014). Model Pembelajaran Bahasa Arab. Yogyakarta: Deepublish.

Wekke, I. S. (2016). Pembelajaran Bahasa Arab di Madrasah. Yogyakarta: Deepublish.

Wekke, I. S., \& Lubis, M. A. (2009). A Multicultural approach in Arabic language teaching: creating equality at Indonesian pesantren classroom life. Sosiohumanika, 1(2).

Ye, Z., Liu, P., Liu, J., Tang, X., \& Zhao, W. (2016). Practice makes perfect: An adaptive active learning framework for image classification. Neurocomputing, 196, 95-106.

Yousafzai, A., Chang, V., Gani, A., \& Noor, R. (2016). Multimedia augmented m-learning: Issues, trends and open challenges. International Journal of Information Management, 36(5), 784-792.

Yusuf, M., \& Wekke, I. S. (2015). Active learning on teaching Arabic for special purpose in Indonesian pesantren. Procedia-Social and Behavioral Sciences, 191, 137-141.

Zakariya, M. (tth). Qadhaya Ulsuniya Tathbiqiyah. Beirut: Dar al-Ilm Li al-Malayin. 